\title{
Country Risk Ratings and Stock Market Movements: Evidence from Emerging Economy
}

\author{
Abdulaziz I. Almahmoud ${ }^{1}$ \\ ${ }^{1}$ College of Business Administration, University of Hail, Hail, Kingdom of Saudi Arabia \\ Correspondence: Abdulaziz I. Almahmoud, College of Business Administration, University of Hail, Hail, \\ Kingdom of Saudi Arabia. E-mail: 1abdulaziz1@gmail.com
}

Received: June 30, 2014

doi:10.5539/ijef.v6n10p88

\begin{abstract}
The empirically relationship between Saudi Arabia's country risk ratings; political, economic, and financial components and its stock market movements is examine from both short and long-run perspectives in this paper. The Autoregressive Distributed Lag (ARDL) methodology is the main instrument of investigation to explore their interdependencies. We find that the country credit risk ratings have a close association with the Saudi Arabia stock market movements. The financial risk factor displays the highest level of sensitivity among all the credit risk ratings. It is sensitive to both economic risk rating and the stock market returns. This development implies that financial risk indicators such as foreign debt servicing, current account balance and exchange rate stability among others should be considered before any strategic investment decision in the country. There is reduced or insignificant political risk sensitivity to other variables. This shows that political risk rating issues are relatively the least considered in Saudi Arabia as shown in this study.
\end{abstract}

Keywords: country credit risks, stock market movements, ARDL

\section{Introduction}

A country's economic and financial environment in addition to its political stability play a crucial role in determining how other external institutions relate to it. The environment could serve as a barrier to both local and foreign investments if it is not properly and efficiently managed with a great measure of transparency and accountability. This is particularly true of emerging markets. A real regulatory environment changes lead to increased foreign portfolio investments (Bekaert, Harvey, \& Lumsdaine, 2002). It is therefore of no gainsaying that a discerning corporate institution or government will create an enabling environment that will attract a considerable inflow of foreign portfolio investments. It generally flows from the above analysis that to achieve this success, emerging economies need to have relatively reasonable economic risks, ensure Political stability and demonstrate relatively moderate financial risks.

The Gulf Cooperation Council (GCC) markets of recent have experienced some legal, regulatory and supervisory changes resulting into increased transparency in the operation of their markets. The liquidity of the markets has increased and operations also opened to foreign investors. Qatar, Bahrain and Kuwait permit foreign stock ownership. Saudi Arabia also in 2006 lifted the restriction that limited foreign residents to dealing only in mutual funds. To obtain foreign capital investment license non-Saudi nationals must apply and get approval from the Saudi Arabian General Investment Authority (SAGIA). Conscious efforts have been made by the various member countries to partially open up their economies, through systematic privatization programs, overhauling their legal and financial institutional infrastructures and use of modern trading platforms have resulted in real development of their markets and manage to attract some foreign direct investments (FDI) to them.

Like all the other members of the GCC, Saudi Arabia's economy is principally based on oil and its related exports, and strong government control over major economic activities (CIA World Factbook). Saudi possesses about $16 \%$ of the world's proven petroleum reserves, ranks as the largest exporter of petroleum, and plays a leading role in OPEC (OPEC Annual Statistical Bulletin, 2013). The petroleum sector accounts for roughly $80 \%$ of budget revenues, $45 \%$ of GDP, and $90 \%$ of export earnings (CIA World Factbook). To diversify its economy Saudi is encouraging the growth of their private sector by offering some mouth watering incentives to private sector equity investors who are willing to invest in the country. 
The core of the diversification efforts of Saudi are on power generation, the petrochemicals and natural gas exploration sectors. The country has an increasing GDP of US\$852.1 billion, US $\$ 895.8$ billion and US\$927.8 billion for the years 2011, 2012 and 2013 respectively (CIA World Factbook). The country also has a public debt of only SAR98.848 million and SAR75.118 million at current prices for 2012 and 2013 respectively (Saudi Arabian Monetary Agency[SAMA], 2013). There is also an increasing stock inward Foreign Direct Investment of US\$223.2 billion and US\$240.6 billion for 2012 and 2013 respectively (World Factbook).

Saudi Arabia stock exchange, the Tadawul, is regulated by the Capital Market Authority. The stock market capitalization of listed companies in the country has been on the upward trend since its inception. The market capitalization of issued shares went up by 10.2 percent to SAR1 400.3 billion from SAR1 271 billion in 2012 (SAMA Annual Report, 2013). The country has a credit rating of AA- for domestic and foreign, and a "stable out-look" from Standard \& Poor, Moody's and Fitch (Rogers \& Sedghi, 2011).

Despite all the above mentioned economic credentials or good indicators, Saudi Arabia's economy faces some challenges which include halting or reversing the decline in per capita income, spreading employment to its citizens of working age population, introducing reforms in the education sector, diversifying the economy, stimulating the private sector, the legal system, bureaucracy among others (Cordesman., 2003; Oxford Business Group 2009; Rogers et al., 2010; House, 2012; Easkins, 2013). These factors pose some uncertainties about the Saudi economic and stock market performance. Nevertheless Saudi Arabia has a seemingly conducive economic environment which could be exploited by investors. This therefore, presents reasonable economic risks. There is also political stability in its own form in terms of the country's ability to carry out declared programs. They are also able to finance their commercial and trade debt obligations, thus demonstrating relatively moderate financial risks.

These indices send strong signals in terms of information content about Saudi Arabia's overall economic health to domestic, international investors and rating agencies among others. Therefore, it will be of interest to empirically explore how these factors (economic, financial and political risks) when taken together or separately can affect the country's stock market performance and vice versa. Country risk ratings assess the probability of a country's default on its debt from a variety of perspectives: from socio-economic condition to growth in the real gross domestic product (GDP), government stability to corruption, to exchange rate stability among others.

The objective of this paper is to empirically investigate the relationship between Saudi Arabia's country risk ratings; political, economic, and financial components and its stock market in order to provide further information for current and potential investors to enable them make better informed investment decisions. In our knowledge this is the first time a study of this nature is conducted on an emerging economy like Saudi Arabia.

Our main instrument of investigation is the Autoregressive Distributed Lag (ARDL) approach formulated by Pesaran and Pesaran (2009) and Pesaran, Shin and Smith (2001), to empirically investigate the relationships between the Saudi Arabia's credit risk ratings (economic, financial and political), and its stock market movements. The ARDL method is adopted because of its econometrics techniques. One important advantage of the ARDL model over other traditional approaches is that it can be used in time-series data irrespective of their order of integration, whether I(0), I(1) and/or fractionally integrated (Pesaran \& Pesaran, 2009). The ARDL approach can also test for cointegration by the bounds testing procedure and can estimate the short-run dynamics and long-run relationships.

The rest of the paper is organized as follows; section two discusses related literature. Section three explains the methodology adopted in this paper. Section four presents the ARDL procedure and discusses its empirical findings. Conclusion and implications are given in section five.

\section{Literature Review}

As a result of globalization of trade and investments cutting across international boundaries, it is wise for participating countries in international business transactions to asses and know the credit worthiness of respective countries. The general motive behind such informed knowledge about the economic and financial condition and sometimes political stability of a country is to be able to evaluate the country credit risks involved in doing business or investing in such a country.

This appetite for increased demand for evaluation of credit worthiness of countries has resulted in the establishment of several rating agencies such as Fitch, Moody's and Standard \& Poor among many others. These risk ratings are considered as indicative of possible future default. A higher rating is seen as a lower risk of default, while a lower score indicates a higher risk of default. Though the primary significance of ratings is due to their impact on interest rates at which countries source for funds in the international financial markets, studies 
have also shown its influence on stock market movements.

Many relevant studies have been carried out on sovereign ratings and their critical roles for encouraging and facilitating investment flows especially in developed economies, but not much work has been conducted on the impact of these ratings on movements of national stock markets, particularly for emerging markets such as Saudi Arabia. Some of the early studies by Erb, Harvey \& Viskanta (1995, 1996a, 1996b) show that there is association or relationship between country credit risk (i.e., the risk that a country defaults on its obligations) and its expected equity returns.

Specifically, Erb et al. (1996a) using data from 35 countries, establish that relationship exists between country credit risk ratings and stock market returns. As a follow up to their earlier work Erb et al. (1996b) investigated the influence of economic, financial and political risks on expected fixed income returns. They show that there is relation between the country risk measures and world bond market expected returns. For the ICRG economic variable, they find positive and significant signs in unhedged, local, and foreign exchange portfolio returns. They also show that the country risk attributes are significant to the real yields of fixed income securities.

Researchers have also studied the effect of rating changes on both bond yield spread and sovereign debt. Reisen and Maltzan (1999) using the three main rating agencies, find that there is mutual interdependencies among rating changes and changes in bond yield spread. The study by Cantor and Packer (1996) also reported similar findings. Among several authors that have provided valuable insight into the influence of rating changes on sovereign debt and corporate securities are Hand, Holthausen and Leftwish (1992) and Richards and Deddouche (1999). The direct impact of rating announcement on corporate securities was confirmed in the works of Hand et al. (1992).

There is also the study by Kaminsky and Schmukler (2001) who examine the influence of sovereign ratings and outlook changes on the sensitivity of emerging financial markets. They find that these variables have substantial influence on both bond and stock markets. A domestic downgrade is associated with an average increase of two percentage points in bond yield spreads and a decrease of one percentage point in stock returns.

Christopher, Kim and $\mathrm{Wu}$ (2012) indicate that sovereign rating information can exert its influence on regional stock market movements. The authors observed that these two variables are related in a positive manner. On the other hand Brooks, Faff, Hillier and Hillier (2004) find no particular sensitivity of emerging markets to rating changes.

Sari, Uzunkaya and Hamoudey (2013) carried out an investigation into the relationships among Turkey's stock market movements and its credit risk ratings. The authors adopted the Autoregressive Lag (ARDL) method. Their findings indicate economic, financial and political variables as having impact on Turkey's stock market movements in the long-run, while in the short-run only the financial and political risk variables are significant.

Various studies also provide information on the spillover effect of sovereign debt rating changes on national stock markets and international debts (Gande \& Parsley, 2005; Ferreira \& Gama 2007; Li, Jeon, Cho, \& Chiang, 2008). Evidence of rating change in one country have a significant effect on sovereign credit spread of other countries is confirmed by Gande and Parsley (2005).

Hammoudeh, Sari, Liu and Uzunkaya (2011) also carried out an extensive study on BRICS's Countries. Their area of the study that is of particular interest to this paper is the individual country risk ratings and their respective national stock markets. The study specifically pointed out China's stock market as being sensitive to all the country risk variables. The degree of sensitivity of the stock market movements to the various risk indicators varies from one country to the other. Among other results, Russia and China display a relatively high sensitivity to political risk.

\section{Data and Methodology}

The country risk variables in our sample are obtained from International Country Risk Guide (ICRG) economic, financial and political risk ratings for Saudi Arabia for the monthly period of January 2005 to December 2012. The ICRG rating system is made up of 22 variables representing three major components of country risk, namely economic, financial and political. These variables essentially represent risk-free measures. There are 5 variables representing each of the economic and financial components of risk, while the political component is based on 12 variables (Hoti, 2003). The specified allowable range for each factor reflects the weight attributed to each factor. A higher score indicates a lower risk and vice versa. Taking the first logarithm difference of the monthly index, we are able to obtain the continuously compounding rates of return for the same period sourcing from Saudi Stock Exchange (TASI). In this paper we us the Autoregressive Distributed Lag (ARDL) approach where we estimate four unrestricted error correction considering each variable as a dependent variable. 


\subsection{The ARDL Approach}

The Autoregressive Distributed Lag (ARDL) approach as developed by Pesaran and Pesaran (2009) involves stages in its implementation. Naturally we check for the order of integration of the time series or variables. Though, this process may be necessary but not a sufficient condition to perform ARDL procedure, because of the econometric properties of the ARDL model. Nevertheless, in this study the properties of the time series are determined by different tests.

In the first place the presence of cointegration among the variables is tested using the bound testing procedure to predict the long-run relationships between a dependent variable and its independent variables. Secondly the ARDL models are formulated based on the results of the initial cointegration test. Finally, the short-run dynamics are then estimated.

\subsection{Bounds Testing and Long-Run Relationships}

The bound test method of cointegration has certain econometric advantages as compared to other methods of cointegration testing. Bounds test method for cointegration is being applied irrespective of the order of the integration of the variables, as the test allows a mixture of 1(1) and 1(0) variables as regressors. Secondly, the short-run and the long-run coefficient of the model can be estimated simultaneously. Thirdly, this technique is suitable for small or finite sample size (Pesaran et al., 2001). We can therefore, construct and estimate the following regressions:

$$
\begin{gathered}
\Delta \operatorname{InTASI}_{t}=\mathrm{a}_{10}+\sum_{i=1}^{n} b_{1 i} \Delta \operatorname{InTASI}_{t-1}+\sum_{i=1}^{n} c_{1 i} \Delta \operatorname{InE}_{t-1}+\sum_{i=1}^{n} d_{1 i} \Delta \operatorname{InF}_{t-1}+\sum_{i=1}^{n} e_{1 i} \Delta \operatorname{InP}_{t-1} \\
+\lambda_{11} \operatorname{InTASI}_{t-1}+\lambda_{12} \operatorname{InE}_{t-1}+\lambda_{13} \operatorname{InF}_{t-1}+\lambda_{14} \operatorname{InP}_{t-1}+\varepsilon_{1 t} \\
\Delta \mathrm{InE}_{t}=\mathrm{a}_{20}+\sum_{i=1}^{n} b_{2 i} \Delta \operatorname{InE}_{t-1}+\sum_{i=1}^{n} c_{2 i} \Delta \operatorname{InTASI}_{t-1}+\sum_{i=1}^{n} d_{2 i} \Delta \mathrm{InF}_{t-1}+\sum_{i=1}^{n} e_{2 i} \Delta \operatorname{InP}_{t-1} \\
+\lambda_{21} \operatorname{InE}_{t-1}+\lambda_{22} \operatorname{InTASI}_{t-1}+\lambda_{23} \operatorname{InF}_{t-1}+\lambda_{24} \operatorname{InP}_{t-1}+\varepsilon_{2 t} \\
\Delta \operatorname{InF}_{t}=\mathrm{a}_{30}+\sum_{i=1}^{n} b_{3 i} \Delta \operatorname{InF}_{t-1}+\sum_{i=1}^{n} c_{3 i} \Delta \operatorname{InE}_{t-1}+\sum_{i=1}^{n} d_{3 i} \Delta \operatorname{InTASI}_{t-1}+\sum_{i=1}^{n} e_{3 i} \Delta \operatorname{InP}_{t-1} \\
+\lambda_{31} \operatorname{InTASI}_{t-1}+\lambda_{32} \operatorname{InE}_{t-1}+\lambda_{33} \operatorname{InF}_{t-1}+\lambda_{34} \operatorname{InP}_{t-1}+\varepsilon_{3 t} \\
\Delta \operatorname{InP}_{t}=\mathrm{a}_{40}+\sum_{i=1}^{n} b_{4 i} \Delta \operatorname{InP}_{t-1}+\sum_{i=1}^{n} c_{4 i} \Delta \operatorname{InE}_{t-1}+\sum_{i=1}^{n} d_{4 i} \Delta \operatorname{InF}_{t-1}+\sum_{i=1}^{n} e_{4 i} \Delta \operatorname{InTASI}_{t-1}+ \\
\lambda_{41} \operatorname{InTASI}_{t-1}+\lambda_{42} \operatorname{InE}_{t-1}+\lambda_{43} \operatorname{InF}_{t-1}+\lambda_{44} \operatorname{InP}_{t-1}+\varepsilon_{4 t}
\end{gathered}
$$

Where:

TASI $=$ Total return index for Saudi Arabia.

$\mathrm{E}=$ Economic risk component of the ICRG's risk ratings.

$\mathrm{F}=$ Financial risk component of the ICRG's risk ratings.

$\mathrm{P}=$ Political risk component of the ICRG's risk ratings.

$\mathrm{a}, \mathrm{b}, \mathrm{c}, \mathrm{d}$, and $\mathrm{e}=$ Short-run coefficient for the TASI and the risk components.

$\lambda \mathrm{s}=$ The long-run coefficients of the ARDL model.

To investigate the presence of long-run relationships among the variables, the bound testing procedure as earlier suggested is used. This procedure is based on the F-test. This test is a test of the hypothesis of no cointegration among the variables as against the existence of cointegration among the variables. The null and the alternative hypotheses are as follows:

$\mathrm{H}_{0}=\lambda 1 \mathrm{j}=\lambda 2 \mathrm{j}=\lambda 3 \mathrm{j}=\lambda 4 \mathrm{j}=0$, where $\mathrm{j}$ represents one of the four variables. (i.e., there is no long-run relationship among the variables).

$\mathrm{H}_{1}=\lambda 1 \mathrm{j} \neq \lambda 2 \mathrm{j} \neq \lambda 3 \mathrm{j} \neq \lambda 4 \mathrm{j} \neq 0$, where $\mathrm{j}$ represents one of the four variables. (i.e., there is long-run relationship among the variables).

In as much as different variables can be assigned different lag-lengths and the researcher has the choice of which 
criteria (Akaike Information Criterion (AIC), The Final Prediction Error (FPE), Schwarz Information Criterion, etc) to choose from, it is important to determine the appropriate optimal lag structure both with and without trend.

The ARDL bound test model follow the postulation by Pesaran et al. (2001) and it is based on the Wald-test (F-statistic) for conintegration test. The results of the cointegration test are evaluated by the lower and upper bounds critical values table in Pesaran et al. (2001). The lower bound is based on the assumption that all the variables are $1(0)$ that is there is no cointegration among the variables. While the upper bound indicates that the variables are 1(1), meaning there is cointegration among the variables. If the computed f-statistics is lower than the lower bound, then the null hypothesis of no cointegration cannot be rejected. But if otherwise, that is the computed f-statistics exceeds the upper bound the null hypothesis of no cointegration is rejected. But when the computed f-statistics falls within the upper and lower bounds, then the tests or results are considered inconclusive.

The estimation of the long-run and short-run relationship among the variables follows next. The estimation of the coefficients of the long-run relationship of the variables is based on the assumption that the bound testing result is conclusive; meaning there is cointegration among the variables. The final step is the estimation of the short-run dynamic coefficients through the use the unrestricted error correction model (URECM) based on the assumption made by Peseran et al. (2001).

\section{Descriptive Statistic and Empirical Results}

This section is in two parts. The first part presents the descriptive statistics used in this study, while the second presents the empirical findings of the tests utilized, reviewing their results and provide an interpretation for each finding. This paper used monthly data from International Country Risk Guide (ICRG) economic, financial and political risk ratings for Saudi Arabia and the monthly stock market returns for the country.

\subsection{Descriptive Statistics}

Table 1 shows the distribution of the data in terms of their mean, standard deviation etc. Country risk ratings are measured in total points. Economic and financial risk components are based on 50 points each, while the political risk components are based on 100 points. A higher country point rating means lower risk. There is a higher country point risk rating for Saudi Arabia based on the data. Figure 1 also shows the distribution of the data over time during the sample period.

Table 1. Descriptive statistics for risk ratings

\begin{tabular}{|c|c|c|c|c|c|c|}
\hline Variables & Mean & Minimum & Maximum & Stand. Dev. & Skewness & Kurtosis \\
\hline Stock Mkt. Return & 0.0536 & -0.0777 & 0.12931 & $\begin{array}{c}0.0454120 \\
0.045412\end{array}$ & 0.669354 & 0.01612 \\
\hline Economic Risk & 45.1275 & 44.3430 & 45.8650 & $\begin{array}{l}0.490645 \\
0.490645\end{array}$ & -0.323454 & -1.38902 \\
\hline Financial Risk & 45.1543 & 44.3430 & 45.8650 & $\begin{array}{l}0.476877 \\
0.476877\end{array}$ & -0.525281 & -1.19864 \\
\hline Political Risk & 73.4573 & 72.3460 & 74.5520 & $\begin{array}{c}0.593253 \\
0.593253\end{array}$ & -0.112875 & -0.99002 \\
\hline
\end{tabular}

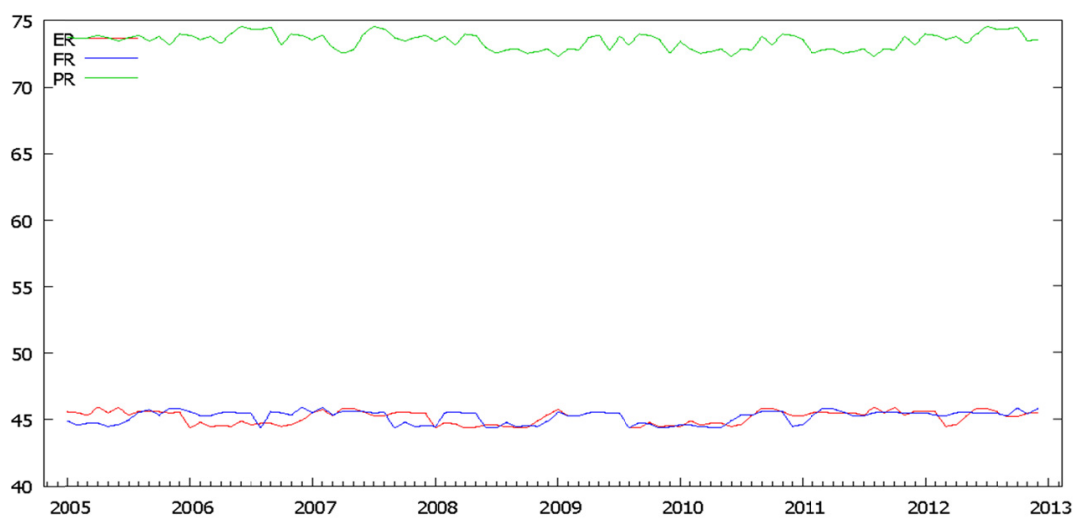

Figure 1. Distribution of economic, financial and political risk ratings 


\subsection{Empirical Results}

The standard Augmented Dickey-Fuller (ADF) unit root test was used to check the order of integration of these variables. The test result is presented in table 2. The results indicate that the variables are integrated $1(0)$ and 1(1). Out of the four variables, three (Index returns, Economic risk and Political risk) have unit root i.e., 1(1), While Financial risk is $1(0)$ variable. For this reason it is justifiable for using the bounds approach or the ARDL model as postulated by Pesaran et al. (2001). The ARDL approach ensures better cointegration results when the sample data is small as opposed to other traditional cointegration models (Haug, 2002)

Table 2. ADF test results

\begin{tabular}{lcc}
\hline & \multicolumn{2}{c}{ ADF $1^{\mathrm{ST}}$ Difference } \\
Variables & $\mathrm{t}$-statistics & $\mathrm{p}$-value \\
\hline Index Returns & -4.75618 & $0.0006267 * * *$ \\
Economic Risk & -2.95609 & $0.03921 * * *$ \\
Financial Risk & -0.754349 & 0.8311 \\
Political Risk & -4.00831 & $0.001369^{* * *}$ \\
\hline
\end{tabular}

\subsection{Bounds Testing and Long-Run Relationships}

The results of the bounds testing procedure is reported in table 3. For the equation with the TASI index (Total return index), as the dependent variable $\left\{\mathrm{F}\left(\operatorname{InTASI}_{t} \mid \operatorname{InE}_{t}, \operatorname{InF}_{t}, \operatorname{InP}_{t}\right)\right\}$. The Wald $\mathrm{f}$-statistics without trend at lag 1 and lag 3 are 4.1825 and 3.958 respectively which are statistically significant (the computed F-statistics are bigger than the upper critical bound value of 3.800). The null hypothesis of no cointegration among the variables is rejected. This indicates the existence of a long-run relationship among TASI index, economic risk, financial risk and political risk. The later three variables being the forcing variables on the TASI equity return index. This is consistent with the findings of Sari, Uzunkaya \& Hamoudey (2013) who investigated the relationship between disaggregated country risk ratings and stock market movements of Turkey. Hammoudeh et al. (2011) who examined the dynamics of BRICS's country risk rating and stock markets also find similar results in three of the BRICS member countries.

For equation 2, with the financial risk rating as the dependent variable i.e. $\left\{\mathrm{F}\left(\operatorname{InP}_{t} \mid \operatorname{InE}_{t}, \operatorname{InTASI}_{t} \operatorname{InP}_{t}\right)\right\}$, the Wald f-statistics with and without trend are also significant; 4.4998 and 4.5486 respectively at $10 \%$ significant level. The null hypothesis of no integration among the variable is once again rejected. Therefore, the TASI index, economic and political risk ratings are forcing variables of the financial risk rating. This is consistent with the findings of Hammoudeh et al. (2011) for the emerging economies of BRICS.

Other cointegration hypotheses are tested using the lag orders. No significant findings are reported for equations

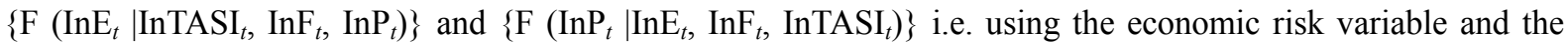
political risk variable separately as dependent variable.

Table 3. Bounds testing procedure results

\begin{tabular}{lccc}
\hline \multirow{2}{*}{ Cointegration Hypotheses } & \multicolumn{2}{c}{ F- statistics } & Lag \\
\hline $\mathrm{F}\left(\operatorname{InTASI}_{t} \mid \operatorname{InE}_{t}, \operatorname{InF}_{t}, \mathrm{InP}_{t}\right)$ & 2.01963 & Without Trend & 1 \\
& 1.19551 & $3.1625^{* * *}$ & 3 \\
& 1.9982 & $2.0040^{* * *}$ & 5 \\
$\mathrm{~F}\left(\operatorname{InE}_{t} \mid \operatorname{InTASI}_{t}, \operatorname{InF}_{t}, \operatorname{InP}_{t}\right)$ & 1.6612 & 1.8304 & 1 \\
& 2.0181 & 1.0208 & 3 \\
$\mathrm{~F}\left(\operatorname{InP}_{t} \mid \operatorname{InE}_{t}, \operatorname{InF}_{t}, \operatorname{InTASI}_{t}\right)$ & & & 5 \\
& & & 1 \\
$\mathrm{~F}\left(\operatorname{InP}_{t} \mid \operatorname{InE}_{t}, \operatorname{InF}_{t}, \operatorname{InTASI}_{t}\right)$ & 2.0074 & 2.0187 & 3 \\
& $4.4998^{* * *}$ & $4.5486^{* * *}$ & 5 \\
& 2.1153 & 2.0821 & 1 \\
\hline
\end{tabular}

Note. $*$ represents significance at $1 \%, * *$ represents significance at $5 \%$ and $* * *$ represents significance at $10 \%$. 


\subsection{Estimating Long-Run and Short-Run Relationships}

The estimation of the coefficients for the long-run relationships in 5 and 6 is conducted using the bounds testing procedure.

$$
\begin{array}{r}
\operatorname{InTASI}_{t}=\mathrm{a}_{1}+\sum_{i+1}^{x} \alpha_{i 1} \operatorname{InTASI}_{t-i}+\sum_{i=0}^{Y} \beta_{i 1} \operatorname{InE}_{t-i}+\sum_{i=0}^{z} \delta_{i 1} \operatorname{InF}_{t-i}+\sum_{i=0}^{1} \eta_{i 1} \operatorname{InP}_{t-i}+\mu_{i 1} \mathrm{~T}+\varepsilon_{1 t} \\
\operatorname{InF}_{t}=\mathrm{a}_{2}+\sum_{i+1}^{x} \alpha_{i 2} \mathrm{InF}_{t-i}+\sum_{i=0}^{Y} \beta_{i 2} \operatorname{InE}_{t-i}+\sum_{i=0}^{z} \delta_{i 2} \operatorname{TASI}_{t-i}+\sum_{i=0}^{1} \eta_{i 2} \operatorname{InP}_{t-i}+\mu_{i 2} \mathrm{~T}+\varepsilon_{2 t}
\end{array}
$$

When the TASI index (equation 5) is the dependent variable, we use an ARDL model without deterministic trend. When the financial risk rating is the dependent variable, we consider both with and without trend. This reasoning is based on the results of the initial procedure. Table 4 shows the sensitivity of both the financial and the economic risks in the long-run. Financial conditions are significant for stock market movements. This means that international investors, multinationals and probably banking and financial institutions should pay particular attention to this risk factor in any relationship with the country. They should put into consideration the financial risk indicators such as foreign debt to GDP, current account balance and exchange rate stability among others. The above result suggest that both the economic risk and the financial risk are inter twined. This result is consistent with the findings of Hammoudeh et al. (2011) who find similar results in some of the emerging economies of the BRICS group. There is reduced or insignificant political risk sensitivity to other variables as compared to the financial and economic risks.

In the short-run, as shown in table 4. The financial and economic risk factors show the most sensitivity. The relationship between the stock market return and each of the economic and financial indicators is positive and statistically significant as it is in the long-run. The political sensitivity is not significant even in the short-run. This shows that variations in socioeconomic conditions, internal and external conflicts, democracy and accountability among others have little or no influence on the stock market index, economic and financial risks of Saudi Arabia. The country's financial risk is sensitive to its own, stock market index and economic risk. The error term is negative and significant.

The result of the financial risk rating; equation 6 is also reported in table 5. TASI index and economic risk rating have slightly significant coefficients, i.e., the financial risk factors show sensitivity to the TASI index and the economic risk rating variables. As mentioned earlier, investors and other relevant agencies must consider the financial risk variables of the country. As regards the financial risk and the TASI index, a well organized, efficient and improved domestic stock market leads to a moderate financial risk.

Table 4. Estimated long-run coefficients

\begin{tabular}{lccc}
\hline Regressor & $\begin{array}{c}\text { InTASI without Trend: } \\
\text { ARDL }(3,0,1,0)\end{array}$ & $\begin{array}{c}\text { InF without Trend: } \\
\text { ARDL }(6,0,3,3)\end{array}$ & $\begin{array}{c}\text { InF with Trend: } \\
\text { ARDL }(6,0,3,3,)\end{array}$ \\
\hline InTASI & - & 0.8952 & $2.6074 * * *$ \\
InE & $3.4832^{* * *}$ & 1.3846 & $3.9785^{* *}$ \\
InF & $3.7377^{* *}$ & - & - \\
InP & 1.1328 & 1.6184 & 0.8673 \\
C & -6.3642 & -2.4261 & -2.3094 \\
T & 0.05073 & - & 0.0416 \\
\hline
\end{tabular}

Note. ${ }^{*}$ represents significance at $1 \%, * *$ represents significance at $5 \%$ and $* * *$ represents significance at $10 \%$.

Table 5. Error Correction Model $\left(\mathrm{ECM}_{-1}\right)$ Results for the selected ARDL

\begin{tabular}{lccc}
\hline Regressor & $\Delta \mathrm{InTASI}$ & $\Delta \mathrm{InF}$ (Without Trend) & $\Delta \mathrm{InF}$ (With Trend) \\
\hline$\Delta \mathrm{InF} 1$ & $-0.6412^{* *}$ & & \\
$\Delta \mathrm{InF} 2$ & $-0.5215^{* * *}$ & $0.3215^{* *}$ & $-0.1867^{* * *}$ \\
$\Delta \mathrm{InF3}$ & & $-0.1967^{* *}$ & -0.1153 \\
$\Delta \mathrm{InE}$ & & & \\
$\Delta \mathrm{InE} 1$ & $\mathrm{I} .0794^{* *}$ & $-0.4457^{* * *}$ & \\
$\Delta \mathrm{InE} 2$ & $1.5528^{* *}$ & & $-0.2509^{* * *}$ \\
$\Delta \mathrm{InE3}$ & & & \\
\hline
\end{tabular}




\begin{tabular}{lccc}
\hline$\Delta \mathrm{InP}$ & 0.7198 & 0.0119 & -0.3115 \\
$\Delta \mathrm{InP} 1$ & 0.0912 & 0.2464 & -0.2281 \\
$\Delta \mathrm{InTASI} 1$ & $0.2217^{* *}$ & & -0.2005 \\
$\mathrm{C}$ & $-3.9975^{*}$ & -0.2917 & -0.5416 \\
$\mathrm{~T}$ & & - & -0.0113 \\
$\mathrm{ECM}(-1)$ & $-0.3752^{* *}$ & $-0.2430^{*}$ & $-0.3665^{*}$ \\
\hline
\end{tabular}

Note. *represents significance at $1 \%, * *$ represents significance at $5 \%$ and $* * *$ represents significance at $10 \%$.

\section{Conclusion and Implications}

This paper empirically examines the short and long-run relationships between Saudi Arabia stock market index movements and its country risk ratings; economic, financial and political. The study employed the ARDL method developed by Pesaran and Pesaran (2009) and Pesaran et al. (2001).

Saudi Arabia has a seemingly conducive economic environment which could be exploited by investors, this presents a reasonable economic risk. There is also political stability in its own form in terms of the country's ability to carry out declared programs. They have also shown their capacity to finance their commercial and trade debt obligations, thus demonstrating relatively moderate financial risks. The economic development, financial adequacy and political stability of Saudi Arabia is of immense importance to many parties especially bi-lateral, local and international investors, as the country is not only the largest economy in the Gulf Cooperation Council (GCC), but also a major player in the oil market being a leading member of the Organization of Petroleum Exporting Countries (OPEC).

The analysis demonstrates that there is a long-run association between the risk ratings (economic, financial and political) and the stock market movements. The Saudi risk ratings are forcing variables on its stock market index. Economic and financial risks have significant and positive relationship with stock market index movements. The sensitivity of the Saudi Arabia financial risk ratings to the economic and the stock market returns variables in this study is significant. This suggests that financial risk indicators such as debt servicing, international liquidity (import cover), balance of payments (current accounts) and exchange rate stability among others are issues to be considered in any strategic investment decisions. There is reduced or insignificant political risk sensitivity to other risk factors as compared to the financial and economic risks. Thus, political risk rating matters are relatively the least in Saudi Arabia as shown in this study.

The findings of this paper have some practical implications for domestic and international investors and policy makers. For policy makers, the ability to deliberately and consistently create an enabling environment to ensure political stability, demonstrating relatively moderate financial risks, and presenting relatively reasonable economic risks that will attract a considerable inflow of foreign port folio investments should be upper most in their minds when considering policy options. While Investors should take into account the long-run economic and financial stability of the country.

\section{References}

Bakaert, G., Harvey, C. R., \& Lumsdaine, R. (2002). The Dynamics of Emerging Market Equity Flows. Journal of International Money and Finance, 3(21), 295-350. http://dx.doi.org/10.1016/S0261-5606(02)00001-3

Brooks, R., Faff, R., Hillier, D., \& Hillier, J. (2004). The National Market Impact of Sovereign Rating Changes. Journal of Banking \& Finance, 28(1), 233-250. http://dx.doi.org/10.1016/S0378-4266(02)00406-5

Cantor, R., \& Packer, F. (1996). Determinants and Impact of Sovereign Credit Ratings. Economic Policy Review, 2(2), 37-53. Retrieved from http://papers.ssrn.com/sol3/papers.cfm?abstract_id=1028774

Christopher, R., Kim, S., \& Wu, E. (2012). Do Sovereign Credit Ratings Influence Regional Stock and Bond Market Interdependencies in Emerging Countries? Journal of International Financial Markets, Institutions and Money, 22(4). http://dx.doi.org/10.1016/j.intfin.2012.01.003

CIA World Factbook. (2014). Saudi Arabia Economy-Overview. Retrieved from https://www.cia.gov/library/publications/the-world-factbook/geos/sa.html Retrieved 5/27/2014

Cordesman, A. H. (2003). Saudi Arabia Enters the twenty-first Century (Vol. 1, p. 224). Greenwood.

Easkins, H. (2013). Will Saudi Arabia Ever Change? New York: Review of Books.

Erb, C. B., Harvey, C. R., \& Viskanta, T. E. (1995). Country Risk and Global Equity Selection. The Journal of Portfolio Management, 21(2), 74-83. http://dx.doi.org/10.3905/jpm.1995.409504 
Erb, C. B., Harvey, C. R., \& Viskanta, T. E. (1996a). Expected Returns and Volatility in 135 Countries. Journal of Portfolio Management, 22(3), 46-58. http://dx.doi.org/10.3905/jpm.1996.409554

Erb, C. B., Harvey, C. R., \& Viskanta, T. E. (1996b). The Influence of Political, Economic and Financial Risk on Fixed Income Returns. The Journal of Fixed Income, 6(1), 7-30. http://dx.doi.org/10.3905/jfi.1996.408169

Ferreira, M., \& Gama, P. (2007). Does Sovereign Debt Ratings News Spill over to International Stock Markets? Journal of Banking and Finance, 31(10), 3162-3182. http://dx.doi.org/10.1016/j.jbankfin.2006.12.006

Gande, A., \& Parsley, D. (2005). News Spillovers in the Sovereign Debt Market. Journal of Financial Economics, 75(3), 691-734. http://dx.doi.org/10.1016/j.jfineco.2003.11.003

Hammoudeh, S., Sari, R., Liu, T., \& Uzunkaya, M. (2011). The Dynamics of BRICS's Country Risk Ratings and Stock Markets, U.S. Stock Market and Oil Price. http://dx.doi.org/10.2139/ssrn.1894210

Hand, J. R., Holthausen, R. W., \& Leftwish, R. W. (1992). The Effect of Bond Rating Agency Announcements on Bond and Stock Prices. The Journal of Finance, 47(2), 733-752. http://dx.doi.org/10.1111/j.1540-6261.1992.tb04407.x

Haug, A. A. (2002). Temporal Aggregation and the Power of Cointegration Tests: A Monte Carlo Study. Oxford Bulletin of Economics and Statistics, 64(4), 399-412. http://dx.doi.org/10.1111/1468-0084.00025

Hoti, S. (2003). Rating Risk Rating Systems. Working Paper, Department of Economics, University of Western $\begin{array}{lr}\text { Australia, } & \text { Perth. } \\ \text { http://www.mssanz.org.au/MODSIM03/Volume } & \text { 03/B09/01_Hoti Rating.pdf }\end{array}$

House, K. E. (2012). On Saudi Arabia: Its People, Past, Religion Fault Lines and Future (p. 167). Knopf.

Kaminsky, G., \& Schmukler, S. (2001). Emerging Markets Instability: Do Sovereign Ratings Affect Country Risk and Stock Returns? Policy Research Working Paper Series, no. 2678, World Bank, Washington, DC. Retrieved from http://elibrary.worldbank.org/doi/pdf/10.1596/1813-9450-2678

Li, H., Jeon, B., Cho, S., \& Chiang, C. (2008). The Impact of Sovereign Rating Changes and Financial Contagion on Stock Market Returns: Evidence from Five Asian Countries. Global Finance Journal, 19(1), 46-55. http://dx.doi.org/10.1016/j.gfj.2007.12.001

OPEC. (2013). OPEC Annual Statistics Bulletin (pp. 7-60).

Oxford Business Group. (2009). The Report Saudi Arabia (p. 202).

Pesaran, M. H., \& Pesaran, B. (2009). Time Series Econometrics Using Microfit 5.0. New York: Oxford University Press. Retrieved from http://ukcatalogue.oup.com/product/9780199563531.do

Pesaran, M. H., Shin, Y., \& Smith, R. J. (2001). Bounds Testing Approaches to the Analysis of Level Relationships. Journal of Applied Econometrics, 16(3), 289-326. http://dx.doi.org/10.1002/jae.616

Reisen, H., \& Maltzan, J. (1999). Boom and Bust and Sovereign Ratings. International Finance, 2(2), $273-293$. http://dx.doi.org/10.1787/251521656447

Richards, A. J., \& Deddouche, D. (1999). Bank Rating Changes and Bank Stock Returns Puzzling Evidence from the Emerging Markets. IMF Working Paper, NO. 99/151. 1-28. http://dx.doi.org/10.5089/9781451857016.001

Rogers, S., \& Sedghi, A. (2011). How FITCH, Moody’s and S\&P rate each country's rating.

Sari, R., Uzunkaya, M., \& Hamoudey, S. (2013). The Relationship between Disaggregated Country Risk Ratings and Stock Market movements: An ARDL Approach. Emerging Market Finance and Trade, 49(1), 4-16. http://dx.doi.org/10.2753/REE1540-496X490101

Saudi Arabia Monetary Agency. (2013). Saudi Arabia Monetary Agency (SAMA) 49th Annual Report (pp. 24$35)$.

\section{Copyrights}

Copyright for this article is retained by the author(s), with first publication rights granted to the journal.

This is an open-access article distributed under the terms and conditions of the Creative Commons Attribution license (http://creativecommons.org/licenses/by/3.0/). 